\title{
How to Spend Money and Win Influence
}

THE study of graduate education which the National Science Board has carricd out (see following page) is bound to have a powerful influence on the development in the United States of public policy on academic research. Even if the Administration takes no notice of what the board has said, things will never be quite the same again. Through the National Sciences Foundation, the National Science Board is the manager of roughly $\$ 500$ million a year, much of which is spent on research grants. Its procedures for allocating money by the decisions of interlocking committees of scientists command respect and have become models for grantgiving in other agencies of the Federal Government. If the National Science Board should itself complain of defects in the present system, people will have to listen. As luck will have it, the new Administration is probably in a mood to listen well.

To begin with, it is only proper to acknowledge that the defects in the present system to which the board has drawn attention will not overywhere be recognized as such. The dissenting views which accompany the board's report are a sufficient proof of that. It is, however, hard to see how there can be serious objections to the proposal that some means should be found of financing separately the overhead component which is at present an essential part of the award of a research grant. This practice may have been sensible enough when research money was a much smaller proportion of the budget of typical universities than it has become, but now there is plenty of evidence that many universities have become unwisely reliant on the research overheads for the general conduct of their affairs. (It would be interesting to know how many institutions would be compelled to abandon plans for libraries of computing centres if overhead payments were scrapped tomorrow.) As the dependence of American universities on the overhead component has grown up in the past few years, it has been something of a surprise that more of them were not more alarmed than they have been about the threat to university autonomy which the practice entails. To be sure, direct Federal support for institutions engaged in graduate education would also have its dangers, but as things are, the potential advantages are much more powerful.

Most controversy about the National Scienco Board's proposals will inevitably centre on the suggestion that there should be Federal grants to selected university departments on a scale sufficient not merely to cover the cost of continuing expenses such as those of longterm research programmes but also generous enough to pay the stipends of the graduate students. Many of the advantages of the scheme are clear. It would, for example, then be much easier to encourage the development of new graduate schools, and there is plenty of evidence in the statistics which the board has assembled that growth in the next few years will have to take place mainly at the institutions which are now among the most excellent and thus most able to compete for funds under the present system. There would also be great benefits in continuing support for some of the university departments in fields where the competition for grants is necessarily somewhat artificial-mathematics is a good example. By the same test, thore is a strong case for Federal support for items of equipment-radio telescopes, for examplewithout a detailed specification in advance of how they will be used. To be sure, a great many departments will be uneasy at the prospect of competing-and perhaps losing--in some national competition for funds like these, but the National Science Board's case is strong.

It is less certain that it would be wise to include stipends for graduate students in the departmental grants. This proposal would probably endow the departments with too much patronage. It would probably be preferable that grants should be made individually to students, possibly by another agency than that responsible for departmental grants. If anything, that solution should help to encourage the kind of diversity the National Science Board would like to see.

What does all this mean for the new Administration? The first thing to be said is that the National Science Board has made an overwhelming case that graduate education should be regarded as a national responsibility which the Federal Government cannot shirk. The problem is to decide which agencies should be responsible for administering these funds and what mechanisms there should be for making wise decisions about their allocation. The National Science Board is less than convincing in its proposals for administrative change, in part at least because it has shrunk from recognizing that its proposals amount to a demand that the Federal Government should accept continuing responsibility for education as a whole. There would be great risks in a system in which responsibility for departmental grants were divided among several agencies. The best solution would be to make the Office of Higher Education responsible for institutional support and to channel funds for the departments, for students and for research grants through the National Science Foundation and such analogous organization as may be needed in other fields. The board has also taken less seriously than it should have done the problems which at present arise because several different agencies share responsibility for grantgiving. Even if graduate schools could rely on a direct subvention of their overhead costs, so that the competition for research grants would be less frenetic, it would still be anomalous that agencies such as NASA and AEC should have such a decisive influence. 